\title{
Jordanian consumers satisfaction with electrical appliances after-sale services
}

\author{
Fathi Alshare ${ }^{a^{*}}$
}

${ }^{a}$ Department of Marketing, Jadara University, Jordan

C H R O N I C L E A B S T R A C T

\begin{tabular}{l} 
Article history: \\
Received: December 22, 2019 \\
Received in revised format: \\
January 302020 \\
Accepted: February 16, 2020 \\
Available online: \\
February 16,2020 \\
\hline Keywords: \\
L.G and Samsung companies \\
Customer satisfaction \\
After-sale services
\end{tabular}

Article history:

Received: December 22, 2019

January 302020

Accepted: February 16, 2020

Available online:

Keywords:

Customer satisfaction

After-sale services

\begin{abstract}
The study aimed to identify the extent of Jordanian costumers' satisfaction with electrical appliances' after-sale services offered by both LG and Samsung companies. The researcher used the analytic descriptive approach for data collection from the primary resources through developing a questionnaire for the purposes of this study. The sample of the study included 400 clients for L.G and Samsung companies. The results of the study indicate a relationship between after-sale services offered by both companies and consumers' satisfaction. In addition, there was a relationship between quality guarantee certificate offered by LG and Samsung companies for electrical appliances and consumers' satisfaction. In light of the results, the study recommended with the necessity of the existence of a specialized team within the company to offer maintenance services, offering financial compensations in case there is a technical error with any product or substituting the product.
\end{abstract}

\section{Introduction}

Given the great competition in the sector of electrical appliances in the commercial markets, it has become dictated to companies to pay more attention for the satisfaction of their customers, through paying more attention to after-sale services. The marketing department in all companies need to identifying customer's needs after purchasing such electrical appliances (AlOmari, et al., 2018, 2020). Providing after-sale service distinguishingly is a key factor in reducing costs and increasing income and profitability, and can constitute a reason for preference in the field of competition between companies (Aljawarneh \& Atan, 2018). Obtaining customer satisfaction is a key factor in establishing a strong long-term relationship for the relevant company, and this leads to customer's loyalty and repeated purchases, and also a source of promotion for their products (AlDa'abseh, et al., 2018). However, many of the large electrical industrial companies in Jordan do not give this area the attention it deserves compared to what competitors are doing in the same industry (Alshare, 2017, 2018). After-sale services are considered one of the thorny issues today in light of the great technological progress, especially among companies producing electrical appliances globally, as these companies seek to acquire a large market share, by satisfying the needs and desires of their customers after completing the purchase process, by providing after-sale services of maintenance, preparation, and guarantee of products. However, in Jordan the interest in after-sale service is still weak, and from here the electrical appliances companies under study must review their marketing policies regarding after-sale services and work on satisfying the needs and desires of their customers. To achieve the purpose of this study, the following questions were formulated; 1 - What is the extent of costumers' satisfaction with the services offered by both LG and Samsung companies? 2- What is the extent of costumers' satisfaction with the quality guarantee certificate offered by both LG and Samsung companies? 3- What is the extent of costumers' satisfaction with the maintenance services offered by both LG and Samsung companies? The importance of this study lies in that it serves the electrical appliances sector in general and LG and Samsung companies in Jordan (target of the study) in particular regarding the importance of after-sale services and costumers' satisfaction with the services they * Corresponding author.

E-mail address: fathisharu04@gmail.com (F. Alshare) 
offer to compete other competitor companies and the reflection of this on country regarding creating job opportunities for the society members and society development. This study aims to urge companies to upgrade after-sale services by achieving the following goals: Identifying the level of customers' satisfaction with after-sale services, identify the factors that affect the level of customer's satisfaction with after-sale services and identifying the extent of consumers' satisfaction with after-sale services' effect on future purchasing decisions.

Nowadays, just products are not enough to satisfy customers' expectation; customers demand instant after sales service as well. Customer satisfaction is a measure of how products and services provided by a company meet or surpass customer expectation (Rokaya \& Al-Ghazzawi, 2018). Customer satisfaction largely depends on how customers are treated before, during and after the sales is made, along with product or service utility (Giri \& Thapa, 2016). Philip Kotler posits that, after sales service is a service provided by the company to a customer after the sale. The cost of attracting a new customer is estimated to be five times the cost of keeping a current customer happy and hence, businesses are conducting customers' satisfaction survey to understand needs and wants of their customer (Aljawarneh \& Al-Omari, 2018). Oliver and Kallenberg (2003) consider satisfaction as the consumer's fulfilment response. It is a judgment that a product or service attribute, or the product or service itself, provides a pleasurable level of consumption-related fulfilment. According to Dick and Basu (1994) 'customer loyalty is viewed as the strength of the relationship between an individual's relative attitude and their repeated patronage'. Moreover, it can be said that customer service and service quality can be put together as both are concerned with meeting customer expectations and the need for satisfying them is to retain them. A customer is a stakeholder of an organization who pays in for the offer (product and/or service) provided to him by the organization. By doing so, the customer has the aim of fulfilling a particular need or want, and to maximize his satisfaction which is when he is happy with the product or service received (Berry \& Parasuraman, 1977).

After sales service has become an important marketing tool for the manufacturing industry globally, Jordan inclusive. The way companies view after sales services has changed due to a rapidly changing business environment, increased use of technology, higher market competition, and higher potential profits in after sales service. According to Saccani, et al., (2007) it is no longer treated as a cost center, but instead, has become a major profit source with profitability ranging up to $45 \%$ of corporate revenues for many business environments. After sales service has to do with a continuous interaction between the service provider and the customer throughout the post-purchase product life cycle. At the time, the product is sold to the customer is formalized by a mutually agreed warranty or service contract. According to Cohen et al., (2006); Oliver and Kallenberg (2003), the exact terms of the warranty or service contract, the characteristics of the customer base, and the nature of the sold product influence the after sales-service strategy of the service provider. Based on Goffin and New (2001) discoveries, after-sales services maximize the value extracted by customers over the entire product life cycle. Kurata and Nam (2010); and Ahn and Sohn, (2009) posit that after-sales services can create sustainable relationships with customers and contribute significantly to customer satisfaction by offering different after-sales services during the various stages of the primary product lifecycle, the provider can ensure product functionality and thereby customer satisfaction (Al-Omari et al., 2020). This can result to a fruitful relationship between the provider and the customer over time, giving a headway for more transactions (Al-Jawarneh, 2016). It is on this note that this research paper wishes to investigate the impact of after sales service dimensions on customer satisfaction and retention with special reference to LG Electronics and Samsung in Irbid Jordan.

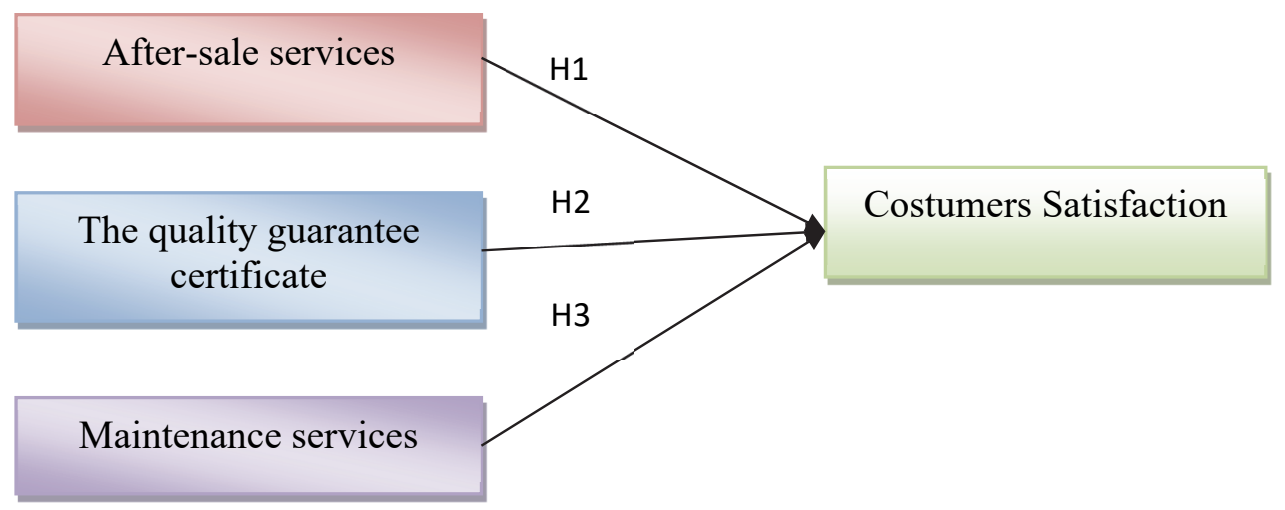

Fig. 1. The proposed study

\section{Literature Review}

\subsection{The Concept Sale Services}

After-sale services are a type of services, as is clear from its name, and what applies to services in general applies to them. Saffar and Obeidat, (2020) views differed in defining the concept of service, as the American Marketing Association defined 
it thus: "It is the activities or benefits that are offered for sale or that are offered in connection with the sold goods. And aftersale services are those services provided in association with the sold items" (Al-Sumaidi \& Al-Alaq, 2002).

In another definition, it is any action, behavior, or type of performance that a particular party performs in the interest of another party, and this activity is essentially an intangible activity (that is, services cannot be displayed in an exhibition, transferred, stored, wrapped or examined before they are purchased). Also, the services do not entail any type of transfer of ownership and are not necessarily related to the sale of a tangible physical product (Malkawi et al., 2018). Al-Sumaidaie (2002) in this definition indicates the followings: Intangible benefits that are offered for sale without being linked to commodities such as insurance, law, electricity, health services, transportation services, etc. Intangible activities (services) that require the use of tangible goods such as renting a property. Services that we purchase along with the goods, such as buying a refrigerator accompanied by maintenance services and this last type is what applies to after-sale services, as consumers usually care about the accompanying services of the commodity such as delivery, installation, maintenance services and availability of spare parts, and services are considered as effective promotional methods.

\subsection{Ways of Offering After-Sale Services}

Factory focused services: this has to do with returning the commodity again to the factory for repair, and this method gives the product huge control over the type of service provided, but it may include some troubles for the consumer (Irtaimeh et al., 2016). Some companies set up service stations spread over different regions of the country to which the consumer transfers the equipment to be repaired in other words maintained, and this method reduces the troubles that the consumer is exposed to and at the same time it reduces product control. Some companies provide their services in a decentralized way and entrust them to distributors or intermediaries, although it is considered one of the best methods due to its ease and suitability to the consumer, but it causes problems for the product due to the lack of control over the type of service provided to the ultimate consumer (Alwagfi et al., 2020).

\subsection{Importance of After-Sale Services and the Weak Interest}

Researchers and specialists unanimously agree on the importance of after-sale services for companies. They also agree that these services and the level of customer and consumer satisfaction are not receiving appropriate attention. Providing excellent after-sale service is a key factor in reducing expenses and increasing income and profitability, and it can constitute a reason for preference in the field of competition between companies, and obtaining customer satisfaction is a key factor in building a long-term profitability relationship for the company, and this leads to customer loyalty and repeated purchases, but nevertheless, many large industrial companies do not give this area the attention it deserves. Services represent the greatest opportunity ever for the growth of returns and profits for many companies, yet some institutions still view after-sale services as an additional burden that must be increased, and customers are increasingly focusing on saving time in all aspects of their lives, so when they buy any product they, they expect the company from which they bought to provide complete solutions starting from installing the device and operating it until returning the product to the company without discussion. The customers are looking for a comprehensive purchase that includes a convenient service that quickly meets a need or solves a problem efficiently, and in many cases, they are ready to pay the cost to obtain such Excellent Service Excellence (Brechbuhl, 2004). Since business institution began offering "solutions" instead of "products" it became clear that selling spare parts and aftersales services had become an important source of profit (Cohen, 2006). Consumer satisfaction has become a central tenet of corporate strategies because it has been proven that the higher the level of consumer's satisfaction, the higher they are loyal to the company and the more profits it generates (Humburg, 2005). There is a close relationship between customer satisfactions on the one hand, and his/her loyalty to the company, its market shares and profits on the other hand (Denove \& Power, 2006). Talaat (1995) listed several advantages that companies can gain from following customers after- sale services as follows: Having a strong position with clients when entering into any new contracts. Ability to keep customers for long periods of time. Identify the strengths and weaknesses of production and marketing policies. Guiding customers on the best methods of goods' use and services, in order to maximize the fulfillment process and preserve the company's reputation. The ability to direct marketing policies to clients and obtain the necessary information. Maximizing knowledge of goods and services for which complete information is not available to buyer. Consolidate the positive aspects in comparison and outperform the aspects of objections that customers usually express. The main purpose of the sales representative is not primarily to sign the contract and deliver the commodity to the prospective customer but rather to include benefiting from this customer as a source of information about new customers (Obaidat, 2004).

\subsection{Types of Products' Services}

According to Abu Alafah (2002), service is a marketing function that aims to increase consumer or industrial buyer satisfaction with the product, which leads to the preference for this product and the frequency of purchase. Service is characterized by the following: It includes technical aspects such as installation, maintenance, and repair, non-technical aspects such as acceptance of sales returns, a credit product, and free delivery of goods at the buyer's location. It begins before production to study consumer needs and propose goods appropriate to these needs, and it extends after the sale process, such as maintenance and repair services and acceptance of returns. It represents one of the promotional elements that the organization depends on to 
attract consumers and one of the tools of competition between institutions (Alshare, 2017). It helps to protect the product, as it represents a kind of relationship between the organization and consumers as it requires constant contact with them. Aftersale services are practiced by the institution producing durable devices and distributors or by agents acting as agents for the producing organization or distributor, in the form of service stations distributed in different regions of the country. After-sale services are usually related to technical products, whether they are durable or not, and after-sales services have several definitions, the most important of which are listed below. After-sale services are all activities that the producer undertakes that would enable the consumer to purchase and secure the best benefit he would get from the commodities by increasing the additional benefits so that they achieve the greatest possible satisfaction for his needs and desires (Al-Askari, 2000). Ziller et al. (1969) define after-sale services as the use of all means capable of giving the user the possible degree of satisfaction with the devices without pre-determining the period of this satisfaction, and to use these methods for free or in return, whether set in the sales contract or not, and this is for the duration of the enterprise's sales. They are everything that is outside the price limits to connect the consumer with a specific product to a competing product of the same nature, by providing many facilities in order to gain this product or service, and to give the greatest possible satisfaction in using this product (Evrard \& Le Maire, 1976). After sales services is also defined as the main idea that the product gives to the commodity in order to satisfy most consumers to the maximum, and aims to repeat the purchase (Ziller et al., 1969).

The study by Hanif et al. (2010) aimed to test the factors responsible for forming satisfaction among consumers of mobile phone services companies in Pakistan, and (250) questionnaires were distributed in the facilitated way and (150) questionnaires were retrieved and were valid for analysis. The results of the study indicated that the factors of price justice and customer services affect customer satisfaction, as it was found that price justice had a greater impact on customer satisfaction compared to the impact of the customer services factor, and the results also indicated the importance and impact of customer satisfaction on the reputation and value of the company providing the service as satisfied customers add value to the mark from while having positive attitudes toward the brand and helping to enhance the reputation of the brand, and in light of these results, the study recommended with the need to construct strong relationships with customers through effective customer services and continue to maintain price fairness.

This study is distinguished from its predecessors by investigating customer satisfaction with the after-sale services provided by (Samsung, LG) for electrical appliances and customer satisfaction, and it may be one of the only studies that dealt with this aspect, for the researcher's best knowledge as it was found through the measurement tool that there is a satisfaction among the customers of both Samsung and LG companies for electrical appliances about the services provided by these companies, but there are some problems that face the customers of both companies from their perspective, which prompted the researcher to recommend those responsible for these companies to attach this thing a great importance to follow-up customers and the realization of their demands. After reviewing the literature, the researcher reached the following hypotheses

$\mathbf{H}_{1}$ : There is a relationship between after-sale services offered by Samsung and LG companies for electrical appliances on costumer's satisfaction.

$\mathbf{H}_{2}$ : There is a relationship between the quality guarantee certificate offered by Samsung and LG companies for electrical appliances on costumer's satisfaction.

$\mathbf{H}_{3}$ : There is a relationship between the maintenance services offered by Samsung and LG companies for electrical appliances on costumer's satisfaction.

\section{Methodology}

This is an analytic descriptive study that aimed to identify consumer's satisfaction with after-sale services offered by Samsung and LG companies for electrical appliances. To achieve the goals of the study, the researcher adopted information resources as follow: These are the data that the researcher relied on by designing a questionnaire to serve the topic and purposes of the current study, so that it covered all aspects based on which the hypotheses were developed and addressed in the theoretical framework, and this questionnaire was distributed to the study sample through the researcher personally. The study population consisted of all customers of Samsung, LG companies for electrical appliances from which a sample of 400 clients was randomly selected. The questionnaire was distributed for the sample and 380 questionnaires were retrieved, 12 questionnaires were excluded because they are not valid for analysis, and 368 questionnaires were analyzed with a percentage of 0.92 .

\subsection{Reliability}

To verify the reliability of the tool, the Cronbach alpha was calculated for all the items and the tool as whole as shown in Table 1. Table 1 indicates that the values of the constant coefficients of Cronbach alpha for the study dimensions ranged between 0.72-0.80 and the coefficient of Cronbach alpha for the instrument as whole reached 0.92 which is acceptable value for application purposes, as most studies indicated that the ratio of acceptance of the stability factor is 0.60 (Sharifs \& Kilani, 2007). 
Table 1

Cronbach alpha for all the items and the tool as whole

\begin{tabular}{lll}
\hline No & Dimension & Cronbach alpha \\
\hline 1 & After-sale services & 0.73 \\
2 & Quality guarantee certificate & 0.80 \\
3 & Maintenance service & 0.72 \\
\hline & Total & 0.92 \\
\hline
\end{tabular}

\subsection{Results}

This section includes a presentation and analysis of the data collected by the researcher through the questionnaire that was distributed to the respondents from Samsung, LG for electrical appliances' clients, in which a description of the demographic and functional characteristics of the respondents were described, and then an analysis of the answers of these individuals to the questionnaire items was performed. The sample of the study included 368 clients of LG and Samsung companies for electrical appliances whom were randomly selected from the study population as shown in Table 2.

Table 2

Distribution of the study sample based on personal variables

\begin{tabular}{|c|c|c|c|}
\hline Variable & Level & Frequency & $\%$ \\
\hline \multirow[t]{3}{*}{ Gender } & Male & 207 & 59.8 \\
\hline & Female & 161 & 40.3 \\
\hline & Total & 368 & 100.0 \\
\hline \multirow[t]{5}{*}{ Age } & Less than 25 years & 19 & 4.8 \\
\hline & 25-less than 35 & 22 & 5.5 \\
\hline & 36 -less than 45 & 284 & 79.0 \\
\hline & Above 45 years & 43 & 10.8 \\
\hline & Total & 368 & 100.0 \\
\hline \multirow[t]{5}{*}{ Educational qualification } & General secondary level and less & 37 & 9.3 \\
\hline & Intermediate diploma & 19 & 4.8 \\
\hline & Bachelor & 270 & 75.5 \\
\hline & Higher studies & 42 & 10.5 \\
\hline & Total & 368 & 100.0 \\
\hline \multirow[t]{4}{*}{ Job position } & Manager & 102 & 25.5 \\
\hline & Employee & 220 & 63.0 \\
\hline & Department head & 46 & 11.5 \\
\hline & Total & 368 & 100.0 \\
\hline
\end{tabular}

Table 2 indicates: The number of male members of the sample reached 207 with a percentage of 59.8, while the number of females reached 161 with a percentage of 40.3. The highest percentage of the sample population distribution according to the age variable was 79.0 for the age group 36- less than 45 years, while the lowest percentage for the age group less than 25 years was at a percentage of $4.8 \%$. The highest percentage of the sample's distribution according to the variable of the educational qualification was $75.5 \%$ for the educational qualification Bachelor's degree, while the lowest percentage $4.8 \%$ for the educational qualification intermediate diploma. The highest percentage of the sample's distribution according to the variable of the job position was $63.0 \%$ for the category employee, while the lowest percentage was $11.5 \%$ for the category department head. Results related to the $\mathrm{H}_{1}$ to check for this hypothesis correctness, mean and SD were calculated for the relationship between after-sale services and customer satisfaction dimension and the one sample t-test was applied on the dimension as whole as shown in Tables 3 .

Table 3

Results of after-sales services on costumer's satisfaction

\begin{tabular}{llllll}
\hline Hypothesis & Mean & SD & T & Sig & Result \\
\hline After-sale services & 3.99 & 0.54 & 36.79 & 0.00 & Accepted \\
\hline
\end{tabular}

Table 3 indicates that there is a statistically significant relationship between after-sales services provided by Samsung and LG for electrical appliances and customer satisfaction, where the value of T was 36.79 and this is a statistically significant value and the five-point standard mark 3 where the mean 3.99 is higher than the standard mark, and this indicates customer satisfaction with the after-sales services provided by Samsung, LG. Results related to $\mathrm{H}_{2}$ to check for this hypothesis correctness, mean and SD were calculated for the items of the relationship between quality guarantee certificate and customer satisfaction and the one sample t-test was applied on the dimension as whole as shown in Table 4.

Table 4

Results of quality guarantee certificate on customer satisfaction

\begin{tabular}{llllll}
\hline Hypothesis & Mean & SD & T & Sig & Result \\
\hline Quality guarantee certificate & 3.83 & 0.60 & 27.66 & 0.00 & Accepted \\
\hline
\end{tabular}


Table 4 indicates that there is a statistically significant between the quality assurance certificate provided by Samsung and LG for electrical appliances and customer satisfaction, as the value of T reached 27.66 which is a statistically significant and the standard score for the five-step 3 where the mean was 3.83 and this value is higher than the standard score, and this indicates customer satisfaction with the quality guarantee certificate provided by my company Samsung, LG. To check for this $\mathrm{H}_{3}$ correctness, mean and SD were calculated for the items of the relationship between maintenance services and customer satisfaction and the one sample t-test was applied on the dimension as whole as shown in Tables 5.

Table 5

Results of the maintenance services provided and customer satisfaction

\begin{tabular}{llllll}
\hline Hypothesis & Mean & SD & T & Sig & Result \\
\hline maintenance services & 4.04 & 0.55 & 37.59 & 0.00 & Rejected \\
\hline
\end{tabular}

Table 5 indicates that there is a statistically significant relationship between the maintenance service provided by (Samsung and LG) for electrical appliances and customer satisfaction, where the value of T was 37.59 which is a statistically significant value and the five-point standard mark 3 and the mean was 4.04 and this value is higher than the standard score, this indicates customer satisfaction with the maintenance service provided by (Samsung, LG).

\section{Conclusions and Recommendation}

There is a statistically significant relationship between the after-sales services provided by the companies (Samsung, LG) for electrical appliances and customer satisfaction, and the results of the study concluded that there was a relationship between after-sales services provided by the companies under study and this study is consistent with Alnazzir (2009) where the researched companies achieved a competitive advantage in the services provided after the sale, which constituted satisfaction of clients. There is a statistically significant relationship between the quality guarantee certificate provided by the company (Samsung, LG) for electrical appliances and customer satisfaction, the results of the study concluded that there is a relationship between the quality guarantee certificate offered and customer satisfaction and is consistent with study of Senthikumar (2011) and Fuzizaden (2011) respectively, in terms of warranty and quality of delivery. There is a statistically significant relationship between the maintenance service provided by the companies (Samsung, LG) for electrical appliances and customer satisfaction, and the results of the study concluded that there is a relationship between maintenance services provided by the companies under study for electrical appliances and customer satisfaction. For the future studies, we may address other topics such as telecommunications services, air transport, banking services and as the recipients of the service feel the service provided after the sale, this contributed to the loyalty of the service recipients to those companies. The researcher believes that customer satisfaction depends on the services provided by companies and thus leads to an increased demand for their products and in turn leads to loyalty to the products of those companies. These issues could be considered for further investigation in future.

\section{Recommendation}

There must be a specialized team in the company to provide maintenance services to its customers. The company must provide sums of money to compensate for the product if there is a technical defect for its customers. The company must ensure that the product is replaced when there is a defect in it to gain customer loyalty towards its products.

\section{Acknowledgement}

The authors would like to thank the anonymous referees for constructive comments on earlier version of this paper.

\section{References}

Abu Alafah, I.A.I (2002). Marketing “Concepts and Strategies”. Alexandria: Horus International Foundation for Publishing and Distribution.

Malkawi, N. M., Al Omari, K., \& Halasa, A. (2018). Intellectual capital as a core competency for competitive advantage: A case study. Journal of Digital Information Management, 16(4).

Saffar, N., \& Obeidat, A. (2020). The effect of total quality management practices on employee performance: The moderating role of knowledge sharing. Management Science Letters, 10(1), 77-90.

Irtaimeh, H. J., Obeidat, A. M., Abualloush, S. H., \& Khaddam, A. A. (2016). Impact of business intelligence on technical creativity: A case study on AlHekma Pharmaceutical Company. European Scientific Journal, 12(28), 502-519.

Rokaya, A. L., \& Al-Ghazzawi, H. (2018). Diversity training and its impact on the employees' organizational commitment: job satisfaction as a moderating variable in the Classic Fashion Apparel Industry company. International Journal of Business and Management, 13(10).

Ahn, J. S., \& Sohn, S. Y. (2009). Customer pattern search for after-sales service in manufacturing. Expert Systems with Applications, 36(3), 5371-5375.

Khairo Al-Da'abseh, T., Saleh Aljawarneh, N. M., \& Mustafa Shwiyat, Z. (2018). Marketing mix startegies and its impact on organizational performance efficiency in The Jordanian company for investment and supply-safeway: An empirical study. Invention Journal of Research Technology in Engineering \& Management, 2(2), 14-23. 
Al-Jawarneh, N. M. S. (2016). Case study: Business management school at the Turkish Republic of North Cyprus and how strategic thinking and planning can improve the performance of the organization to maintain stable between competitors. Invention Journal of Research Technology in Engineering \& Management (IJRTEM), 1(5), 64-72.

Aljawarneh, N. M. S., \& Atan, T. (2018). Linking tolerance to workplace incivility, service innovative, knowledge hiding, and job search behavior: The mediating role of employee cynicism. Negotiation and Conflict Management Research, 11(4), 298-320.

Aljawarneh, N., \& Al-Omari, Z. (2018). The role of enterprise resource planning systems ERP in improving customer relationship management CRM: An empirical study of safeway company of Jordan. International Journal of Business and Management, 13(8), 86-100.

Alnazzir, N. N. (2009). The impact of relationship marketing and motivation on customer loyalty to the organization. Master Thesis, College of Business, Middle East University, Jordan.

Al-Omari, Z. S., Aljawarneh, N., Davut, S., \& Salah, A. (2018). The Impact of Marketing Mix Elements on Forming Mental Images about Islamic Banks in Jordan: An Empirical Study. OFFICIAL, 12, 54.

Al-Omari, Z., Alomari, K., \& Aljawarneh, N. (2020). The role of empowerment in improving internal process, customer satisfaction, learning and growth. Management Science Letters, 10(4), 841-848.

Alshare, F.A. (2017). The effect of brand awareness on brand loyalty: Mediating role of brand commitment. European Journal of business and Management, 9(36), 38- 47.

Alshare, F., Alkhawaldeh, A. M., \& Eneizan, B. M. (2019). Social Media Website's Impact on Moral and Social Behavior of the Students of University. International journal of academic research in business and social sciences, 9(3).

Alshare, F. (2018). The Role of the Integrated Marketing Communications in highlighting the competitive advantage in the Jordanian Telecommunication Companies (Orange Company: Study Model, Human resource management academic research society, 8(4), 573-598.

Al-Sumaidaie, M.A.B. (2002). Fundamentals of comprehensive and integrated marketing. Dar Al-Manhaj Publishing, second edition, Oman.

Alwagfi, A. A., Aljawarneh, N. M., \& Alomari, K. A (2020). Work ethics and social responsibility: Actual and aspiration. Journal of Management Research, 12(1), 26-36.

Berry, L. L., \& Parasuraman, A. (1997). Listening to the customer--the concept of a service-quality information system. MIT Sloan Management Review, 38(3), 65.

Brechbuhl, H. (2004). Best practices for service organizations, Business Strategy Review, 15(1), 68-70.

Cohen, M. A. (2006). Winning in the aftermarket. Harvard Business Review, 84(S), 129-138.

Denove, C., \& Power, J.D. (2006). How every great company listens to the voice of the customer, portfolio.

Dick, A. S., \& Basu, K. (1994). Customer loyalty: toward an integrated conceptual framework. Journal of the Academy of Marketing Science, 22(2), 99-113.

Evrard, Y., \& Le Maire, P. (1976). Modèles et décision en marketing. Dalloz.

Fazlazah, A., Bagerzadah, F., \& Mahadi, P. (2011). How after - sale service quality dimensions affect customer satisfaction. African Journal of Business Management, 5(17), 7658-7664.

Giri, S., \& Thapa, K. (2016). A Study of Customer Satisfaction on After Sales Service of Two Wheelers in Kathmandu Valley. Journal of Business and Social Sciences Research, 1(1), 1-21.

Goffin, K., \& New, C. (2001). Customer support and new product development-An exploratory study. International Journal of Operations \& Production Management, 21(3), 275-301.

Hanif, M. Hafeez, S., \& Raza, A. (2010). Factors affecting customer satisfaction. International Research Journal of finance Economics Issue, 60.

Homburg, C., Koschate, N., \& Hoyer, W. D. (2005). Do satisfied customers really pay more? A study of the relationship between customer satisfaction and willingness to pay. Journal of Marketing, 69(2), 84-96.

Ziller, R. C., Hagey, J., Smith, M., \& Long, B. H. (1969). Self-esteem: a self-social construct. Journal of Consulting and Clinical Psychology, 33(1), 84.

Kurata, H., \& Nam, S. H. (2010). After-sales service competition in a supply chain: Optimization of customer satisfaction level or profit or both?. International Journal of Production Economics, 127(1), 136-146.

Obaidat, M. (2004). Consumer behavior, a strategic approach. Wael Publishing House, Fourth Edition, Amman.

Oliver, R., \& Kallenberg, R. (2003). Managing the transition from products to services. International Journal of Service Industry Management, 14(2), 160-172.

Saccani, N., Johansson, P., \& Perona, M. (2007). Configuring the after-sales service supply chain: A multiple case study. International Journal of Production Economics, 110(1-2), 52-69.

Senthikumar, N., Ananth, A., \& Arulraj, A. (2011). Impact of corporate social responsibility on customer satisfaction in banking service. African Journal of Business Management, 5(7), 3028-3039.

Talaat, A.H. (1995). The Art of Excellent Selling, Cairo, 2nd Edition.

Tarawneh, K. A. (2010). Measuring customer satisfaction of medical devices and equipment trading institutions with marketing activities Jordan, $\mathrm{PhD}$ thesis, Amman Arab University, Jordan. 
(C) 2020 by the authors; licensee Growing Science, Canada. This is an open access article distributed under the terms and conditions of the Creative Commons Attribution (CC-BY) license (http://creativecommons.org/licenses/by/4.0/). 